\title{
8
}
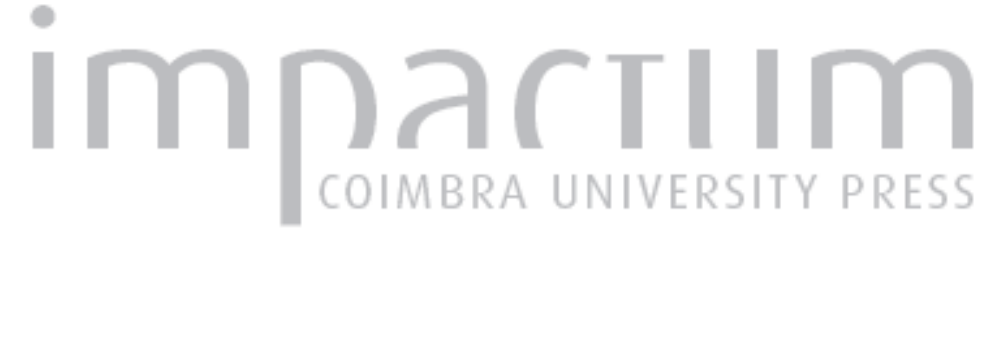

\section{The regional policy in the EUMS from central and eastern Europe between decentralisation and recentralisation}

Autor(es): $\quad$ Horga, loan; Ghimis, Ana Maria Costea Publicado por: Centro de Informação Europe Direct de Aveiro; Centro de Estudos

URL

persistente:

URI:http://hdl.handle.net/10316.2/37112

DOI:

DOI:http://dx.doi.org/10.14195/1647-6336_12_7

Accessed : $\quad$ 26-Apr-2023 10:21:25

A navegação consulta e descarregamento dos títulos inseridos nas Bibliotecas Digitais UC Digitalis, UC Pombalina e UC Impactum, pressupõem a aceitação plena e sem reservas dos Termos e Condições de Uso destas Bibliotecas Digitais, disponíveis em https://digitalis.uc.pt/pt-pt/termos.

Conforme exposto nos referidos Termos e Condições de Uso, o descarregamento de títulos de acesso restrito requer uma licença válida de autorização devendo o utilizador aceder ao(s) documento(s) a partir de um endereço de IP da instituição detentora da supramencionada licença.

Ao utilizador é apenas permitido o descarregamento para uso pessoal, pelo que o emprego do(s) título(s) descarregado(s) para outro fim, designadamente comercial, carece de autorização do respetivo autor ou editor da obra.

Na medida em que todas as obras da UC Digitalis se encontram protegidas pelo Código do Direito de Autor e Direitos Conexos e demais legislação aplicável, toda a cópia, parcial ou total, deste documento, nos casos em que é legalmente admitida, deverá conter ou fazer-se acompanhar por este aviso.

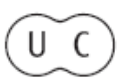


DEBATER

A EUROPA

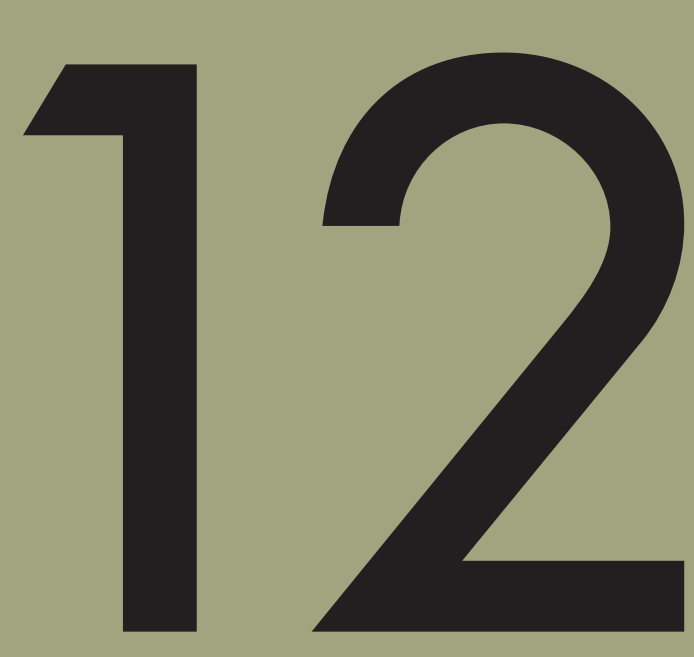

jan-jun 2015

POLITICAS REGIONAIS DA UE

EU REGIONAL POLICIES 


\title{
The Regional Policy in the EUMS from Central and Eastern Europe between Decentralisation and Recentralisation
}

\author{
Ioan Horga \\ Professor at Oradea University, Romania \\ Jean Monnet Chair in Euro-regional Studies \\ Co-director of the Institute for the Study Euro-regional Oradea-Debrecen \\ E-mail: ihorga@uoradea.ro
}

Ana Maria Costea (Ghimiş)

National School of Political and Administrative Studies, Bucharest, Romania E-mail: anamaria.ghimis@yahoo.com

\begin{abstract}
During the accession process and after they became members of the European Union, the Central and Eastern states went through a process of decentralization that emphasized the local and the regional level. Although the process was not complete, after the financial crisis erupted, these states began to develop a centrifugal behaviour are started a recentralization process that decreased the competences of local and regional authorities. The present article argues that undeniably the European Commission through its regional policy has been an important driving force regarding the process of territorial decentralisation in Central and Eastern European countries. However, this influence has generated different outcomes, given its lack of clear perspective and competences.
\end{abstract}

Keywords: Central And Eastern countries; the EU; decentralization; recentralization; local and regional level 


\section{Introduction}

The enlargement process from 2004 and 2007 was possible due to the adoption of the membership criteria by the member states. It is well known the fact that besides the three criteria that were adopted in Copenhagen in 1993 (the political, economic one and the acquis comunitaire), in 1995 in Madrid the strengthened administrative capacity criterion was added. The regular evaluation and monitoring of progress analysis for the countries from Central Eastern Europe highlights the developments that took place at the level of administration and public management system ${ }^{1}$.

Pollitt and Bouckaert highlight five different reform models on the administration and the management of public systems, from a very narrow and limited model to a very stretched and broad span of reform. Choosing one of these models has tremendous practical implications for the content of a reform programme, for the choice of the reform projects, but also for the sequence and the timing of the reform portfolio. It also requires different tactical choices to be made. One of the issues that can be arisen here is how many degrees of freedom there are in reforming the public sector ${ }^{2}$.

The first proposed model has a span of reform which is limited to single organizations within the public sector. In this sense, the "public management is a merger of the normative orientation of traditional public administration and the instrumental orientation of general management." 3 In practice, this means that private-sector management techniques are imported into the public sector ${ }^{4}$.

The second model has a broader span of reform which looks beyond single organisations to clusters of public sector organisations. There is the question of relationships, (e.g. hierarchies of organisations) in order to have good delivery service and policy implementation. This requires a vision on the architecture and the mapping of the public sector ${ }^{5}$

The third model includes the interface of the public sector, but also the civil society. This interface needs to be reformed too, which in some cases requires civil society to be

1 IANCU, Diana Camelia - Uniunea Europeana si Administratia Publica. Iasi: Polirom, 2010, pp. 126-127.

2POLLITT, Christopher; BOUCKAERT, Geert - Public Management Reform: A Comparative Analysis. 2nd expanded edn. Oxford: Oxford University Press, 2004.

3 PERRY, James L.; KRAEMER, Kenneth L. - Public Management: Public and Private Perspectives. California: Mayfield, 1983.

4 Ch. POLLITT, op.cit., p. 97

5 Idem 
(re)built. This requires the recognition of civil society as a partner in reform. Therefore, platforms for exchange, transparent discussions and contradictory debates are necessary to reform the public sector in a sustainable, legitimate, and transparent way ${ }^{6}$.

The fourth model goes beyond the infrastructural level and includes the supra-structure that is also involved in the reform process. This reform's scope includes the realm of ideas and ideologies, culture and values within a society. Reforming the public sector includes not just its infrastructure (organisations and their interactions within the public sector and its civil society) but also its supra-structure. Although this does not mean that identities of communities or nations need to change, it does imply that practices are based on the belief of systems with norms and values, cultures and ideas ${ }^{7}$.

The fifth model goes beyond the fourth one and includes all elements of the system. This requires a reform strategy which includes the major steering mechanisms in society, depending on the state structure itself. Market mechanisms are obvious within the private sector. Budget mechanisms are clear within the public sector. In a mixed economy, you also may have consensual allocation of resources amongst non-profit organisations. Public sector reform affects the proportions and regulates the allocation mechanisms of all these public, private and not-profit sectors. It also affects the allocation mechanisms within the public sector using hierarchies (budgetary top-down distribution with e.g. envelopes), markets (market type mechanisms such as vouchers or competitive tendering) or networks (consensual distribution $)^{8}$.

Looking to see which of the five aforementioned models had been implemented in the public administration reform and management from Central and Eastern Europe states, we started our analysis from Bouckaert's finding that the public administration and public management system in this region present themselves with chosen mixed models of "publicsector reform, and these choices have changed over time " $"$.

6 Idem

7 BOUCKAERT, Geert - "Cultural Characteristics from Public Management Reforms Worldwide." In SCHEDLER, Kuno; PRÖLLER, Isabella (eds). Cultural Aspects of Public Management Reforms. Amsterdam: Elsevier, 2007, pp.29-64.

8 BOUCKAERT, Geert - Public Sector Reform in Central and Eastern Europe, Halduskultuur, vol 10, 2009 , pp. 98 
Since the available space is limited within this paper, we will try only to look at the evolution of public administration through local autonomy and decentralization ${ }^{10}$ which will give us the strength to express a phenomenon that we want to follow over the course of a decade, from decentralization to re-centralization. These manifestations will be highlighted throughout the two following chapters. Firstly, we will emphasize the decentralization within Central and Eastern European countries regarding their accession moment from 2004 and 2007. Secondly, we will discuss about the process of re-centralization during the postaccession period. Among the identified manifestations we will mention only 3 that will be followed throughout the paper: the existing elected regional and local public authorities and their collectivities; the legal recognition of rights and obligations of regional and local administrative authorities that are necessary in order to manage the interests of the represented collectivities; the existing transfer of powers, responsibilities and resources from central to local and regional administrative authorities ${ }^{11}$.

\section{Regionalisation and Decentralisation}

Regional policy design is the result of a process of multi-level decision-making between supra-national, national and sub-national actors. The implementation of this policy in Central and Eastern Europe varies greatly ${ }^{12}$. Some countries, like Poland and the Czech Republic, decentralized power creating strong and independent regional governments. Others, like Romania, Hungary or Bulgaria, only delegated administrative responsibilities to regional offices, failing to devolve power and create regional governments. The cause of this variation lies in the actors' diffuse role in decision-making on regional policy ${ }^{13}$. To understand the meaning of regionalisation within the new Member States, we should take into account the a number of economic and structural factors, explicitly, changes in productive systems, accelerated market integration on sector bases, as well as the increasing competition between different economic

10 The other principles - subsidiarity, openness and transparency, partnership and cooperation, nondiscrimination, proportionality, accountability, efficiency and effectiveness, rule of law will be retained only for those elements that relate to the topic that we have proposed.

11D.C. Iancu (2010) Uniunea Europeana si Administratia Publica, Iasi, Polirom, p. 127

12 The topic was of great interests for many authors. We mention one of the most recent works: PALERMO, Francesco; PAROLARI, Sara - Regional Dynamics in Central and Eastern Europe New Approaches to Decentralization. Brill Online: Leiden, 2013.

13 UNITA, Ramona - Joining the EU's Multi-Level System of Governance - is there an East European Model of Regionalisation?" in HORGA, Ioan; BARBULESCU, Iordan Gh; IVAN, Adrian et al. - Regional and Cohesion Policy. Insights into of the Partership Principle in the New Policy Design. Debrecen: Debrecen University Press \& Oradea University Press, 2011. 
areas after the abolition of most barriers regarding the circulation of goods and capitals. ${ }^{14}$

The principle of local autonomy and decentralization, generally sketched with direct reference to regional policy, multilevel governance and efficient allocation of structural funds, is considered to be an appropriate presence regarding the reforms from EU Member States and candidate countries ${ }^{15}$.

The beginning of leaving aside the centralized administration model, inherited from the communist period, was done differently from country to country in Central and Eastern Europe $^{16}$, as aforementioned. The tendency toward maintaining some degree of centralism or even toward certain recentralization can be observed in the region throughout a period of 25 years of transition. According to Enlander ${ }^{17}$ during the early trasition period, there were mainly four causes, which stem from the specific situation of transforming countries: a) the need of the central government to maintain control of economic and political development within the still volatile post-communist transformation; b) the need to control the distribution of scarce resources during a transformational recession or outright crisis; c) the need to control economic and social differences among territorial units, so as to prevent the marginalization of some regions that could have resulted in social and political tensions that would endanger the new regime; and d) the need to formulate policies aimed at maintaining national integration in a general atmosphere of societal fragmentation, resulting from the transformation processes ${ }^{18}$. Looking at the four mentioned factors throughout the 25 years of transition period, we can notice that regarding the first factor, on the spur of the Europeanization process, this action has been limited, while the other factors continued to influence the decentralization process as part of the accession process towards the EU. They even intensified during the economic crisis especially after 2007.

14 TATUR, Melanie - "Conceptualising the Analysis of 'Making Regions' in Post Socialist Europe." In TATUR, Melanie - The Making of Regions in Post-socialist Europe: The Impact of Culture, Economic Structure and Institutions Case Studies from Poland, Hungary, Romania and Ukraine, Vol. 1, Wiesbaden, Vs Verlag, 2004, pp.11-23.

15 The European Parliament resolution on Agenda 2000 and Council Regulation no. 1659/98 on decentralized cooperation, as last amended by Council Regulation no. 625/2004189, as amended and supplemented.

16 KRUGLASOV, Anatoliy - „Central and Eastern Europe Regional Reforms: From Dismantling a Soviet Model to Europeanizing a National One.' In PALERMO, Francesco; Parolari, Sara, Regional Dynamics in Central and Eastern Europe New Approaches to Decentralization. Leiden: Brill Online, 2013 pp. 8-34.

17 ELANDER, I. - "Between centralism and localism: On the development of local selfgovernment in postsocialist Europe". Paper presented at conference, Democratization and Decentralization: Four Years of Local Transformation in Central and Eastern Europe, Krakow, 2-6 August, 1995.

18 ILLNER, Milka - „The Territorial Dimension of Public Administration Reforms in East-Central Europe,” in Polish Sociological Review , vol. 1., no. 117 [1997]:, pp. 23-45. 
If we analyze each country, we can notice that decentralization addressed by national governments in Central and Eastern Europe, at least at the level of discourse, after the events from 1989-1990, the introducing of local autonomy and decentralization was done after signing the Association Agreements with the EU and amid financial assistance from the EU. This topic of the Europeanization impact on the introduction of local autonomy and decentralization in Central and Eastern Europe is seen by scholars as top-down ${ }^{19}$ action which translates to some as an external pressure ${ }^{20}$ or for other as part of the imposed conditionalities $^{21}$.

Out of the large number of countries in the 2004 accession wave, with a strong assistance from PHARE, Hungary was the first to create the NUTS regions in 1994. Still a candidate, Romania adopted the necessary legislation only in 1998. Hughes underlines that as Hungary never had regions and never considered it needed them, regionalization was a great challenge. The same was perceived by Romanian politicians. It was felt that the pressure to adopt the acquis comunitaire implied regionalization following the NUTS classification ${ }^{22}$. This implicit pressure was mainly felt through the comments of the Country Regular Reports. These reports can moreover be considered guiding documents to what results are expected from the regionalization process. The repeated criticism of the administration's insufficient capacity in implementing regional policy can be understood as insufficient decentralization or weak regional administrative capacity. For instance, in its 1998 report, the European Commission emphasized the national progress in the public administration reforms from the Czech Republic and listed among the successful actions the creation of regions and among failures, the lack of authorities' interest to sign the European Charter of Local SelfGovernment $^{23}$. A year later, however, the Czech Republic ratified the Charte ${ }^{24} \mathrm{r}$. In 2000, the European institution focuses its attention on the decentralization process and the slow

19 KEATING, Michael; HUGHES, James - The Regional Challenge in Central and Eastern Europe. Territorial Restructuring and European Integration. Brussels: Peter Lang, 2003.

20 BOUCKAERT, Geert - "Public Sector Reform in Central and Eastern Europe". Halduskultuur, 2009, vol 10, p.96.

21

KEATING, Michael; HUGHES, James - The Regional Challenge in Central and Eastern Europe. Territorial Restructuring and European Integration. Brussels: Peter Lang, 2003.

22 HUGHES, James, SASSE; Gwendolyn; GORDON, Claire E - EU enlargement, Europeanisation and the dynamics of regionalisation in the CEECs." In KEATING, Michael; HUGHES, James (eds.) The Regional Challenge in Central and Eastern Europe: Territorial Restructuring and European Integration. Regionalism \& federalism (vol. 1). Brussels: Peter Lang, 2003, p.75.

23 European Commission (1998) 1998 Regular Report from the Commission on Czech Republik's Progress Towards Accession, Brussels, p. 8

24 European Commission (1999) 1999 Regular Report from the Commission on Czech Republik's Progress Towards Accession, Brussels, p. 12 
pace of its development ${ }^{25}$. The years of 2001 and 2002 brought significant improvements in the field (by creating and clarify the powers of regional authorities ${ }^{26}$. In 2003 the Commission mentioned that the process of decentralization to local and regional levels was almost completely ${ }^{27}$.

After a difficult start, compared to the Czech Republic's case, the Commission highlighted and suggested in its report from 2000 that the Slovak law requires a local government $^{28}$. In 2001 constitutional revision, administrative reorganization and reformulation of a package of laws on decentralization of public administration and transfer of powers from the state to the regions bring positive signals to the European Commission ${ }^{29}$. In 2003, the Commission considered the implementation of the administrative reforms and the strengthening of local autonomy as signs of change $\mathrm{e}^{30}$.

The 1998 report emphasizes that Hungary needed to implement the objective and the principle of partnership and to reinforce the administrative and institutional capacity ${ }^{31}$. Although it received substantial assistance through PHARE program in paving the way to regional policy implementation, the seven established regions had limited success. In 2001, the European Commission highlighted that fact that the transfer of local responsabilities should be sustained by a proportional allocation of resources ${ }^{32}$. The reports from 2002 and 2003 emphasized the positive evolution of decentralization to as more transparent and efficient way ${ }^{33}$. Especially after 1994, Hungary moved from centralisation to cautious and limited decentralization after transition, mostly due to the weak and half-hearted pressure

25 European Commission (2000) 2000 Regular Report from the Commission on Czech Republik's Progress Towards Accession”, Brussels, p. 19.

26 European Commission (2001) 2001 Regular Report from the Commission on Czech Republik's Progress Towards Accession, Brussels, p. 18; European Commission (2002) 2002 Regular Report from the Commission on Czech Republik's Progress Towards Accession, Brussels, p. 21

27 European Commission (2003) 2003 Regular Report from the Commission on Czech Republik's Progress Towards Accession, Brussels, p. 11

28 European Commission (2000) 2000 Regular Report from the Commission on Slovak Republik's Progress Towards Accession, Brussels, p. 16

29 European Commission (2001) 2001 Regular Report from the Commission on Slovak Republik's Progress Towards Accession, Brussels, pp. 16, 24

30 European Commission (2003) 2003 Regular Report from the Commission on Slovak Republik's Progress Towards Accession, Brussels, p. 11

31 European Commission (1998)1998 Regular Report from the Commission on Hungary's Progress Towards Accession, Brussels, p. 32

32 European Commission (2001) 2001 Regular Report from the Commission on Hungary's Progress Towards Accession, Brussels, p. 16

33 European Commission (2002) 2002 Regular Report from the Commission on Hungary's Progress Towards Accession, Brussels, p. 21 ; European Commission (2003) 2003 Regular Report from the Commission on Hungary's Progress Towards Accession, Brussels, p. 12 
from the European Commission. Most of this pressure had effects before the accession in $2004^{34}$.

In the case of Bulgaria in the Commission's 2004 report, there is specified the need to clarify the powers/competences and budgets of central and local administrations ${ }^{35}$. Similar comments were subsequently offered also by the Country Reports from 2005 and 2006 respectively. ${ }^{36}$

In the case of Poland, the European Commission considered in 1999 the regionalism as a success ${ }^{37}$. Poland is considered to be the only country among new Member States where there is clear correlation between the NUTS II and the meso-level of government ${ }^{38}$. Apparently the reformed framework of regional policy from Poland seemed to reflect largely the idea of decentralisation, subsidiarity and partnerships. In fact by means of the regional contracts sub-national self government through the marshals (democratically-elected voivodhips' representative bodies) have been enabled to participate in the process of decisionmaking in all issues concerning regional development ${ }^{39}$.

Indeed, emphasis on the development of this sort of contractual relationships in regional policy making can also be reasonably related to the Polish government's commitment to prepare for the EU accession ${ }^{40}$. The new planning framework for regional administration and its development was embraced with satisfaction by the European Commission ${ }^{41}$, thus with the accession of Poland to the EU the system of regional contracts merged directly into the broader framework of EU cohesion policy ${ }^{42}$, to which now almost three-fourths of the Polish is related. The year of 2002 brings a strengthening of local self-government in Poland in terms

34 POGATSA, Zoltan - "The Recentralisation of the Economic Development in Hungary." In PALERMO Francesco; PAROLARI, Sara - Regional Dynamics in Central and Eastern Europe New Approaches to Decentralization, S.1: Brill Online, 2013, pp. 147-174.

35 European Commission (2004) 2004 Regular Report from the Commission on Bulgaria's Progress Towards Accession, Brussels, p. 16

36 European Commission (2005) 2005 Regular Report from the Commission on Bulgaria's Progress Towards Accession, Brussels, pp 7-8 ; European Commission (2006) "2006 Regular Report from the Commission on Bulgaria's Progress Towards Accession”, Brussels, p. 6

37 European Commission (2000) 1999 Regular Report from the Commission on Poland's Progress Towards Accession, Brussels, 8 November 2000

38YODER J. - "Decentralisation and Regionalisation after Communism: Administrative and Territorial Reform in Poland and the Czech Republic”, in Europe-Asia Studies, Vol. 55, No.2, 2003, pp. 263-286.

39 GLOWACKI, Viktor - „Regionalization in Poland.” In MARCOU, Gérard - Regionalization for Development and Accession to the EU: A Comparative Perspective. Budapest: The Local Government and Public Reform Initiative, 2002, pp. 105-137.

40 Idem

41 European Commission(2000) 2000 Regular Report from the Commission on Poland's Progress Towards Accession, Brussels, p. 67.

42 SZCZERSKI, Krzysztof - "Securing Growth and Cohesion in Europeanized Conditions. The Role of Regional Development Bodies in Poland." In PALERMO, Francesco; PAROLARI, Sara - Regional Dynamics in Central and Eastern Europe New Approaches to Decentralization. Leiden: Brill Online, 2013 pp. 175-199. 
of political and financial decentralization ${ }^{43}$, but in 2003 the Commission reminds the Polish authorities that local reforms and their consolidation is a priority ${ }^{44}$. The Polish specialists in European integration and practitioners have frequently advocated that the Polish public administration still appears poorly developed ${ }^{45}$ and that the post-accession capacity to absorb the structural funds was, on average, relatively $\operatorname{low}^{46}$. But comparing the situation from Poland with the other states from the region, the Polish developed was a positive one, fact that was evidenced especially during 2007-2013.

According to the 1998 report, the public administration from Slovenia appeared to be centralized, rather passive in taking the necessary reforms ${ }^{47}$. In 1999, the situation was almost unchanged, although the Commission announced the existence of local authorities but it does not make any comment about them ${ }^{48}$.

Regarding Romania, the Commission Report from 2003, taking into consideration the decentralized process, that there is a considerable lack of transparency in the financial transfer to the local county level, believes there is a threat to the very existence of local autonomy ${ }^{49}$. The same document highlighted the current legal framework that was unclear, Romania lacking a strategy for managing the process of decentralization in a transparent and stable way $^{50}$.

In 2004, the Commission reiterated Romania's still unsolved problem of responsibilities' transfer to the local level showing that they were not followed by doubling adequate financial transfers. However, the Commission considers that "the Romanian authorities have made considerable effort to develop a strategy to manage the process of

\footnotetext{
43 European Commission (2002) 2002 Regular Report from the Commission on Poland's Progress Towards Accession, Brussels, pp. 22-23

44 European Commission (2003) 2003 Regular Report from the Commission on Poland's Progress Towards Accession, Brussels, 2003, p. 14

45 FERRY, Martin - "Regional Policy in Poland on the eve of EU membership: regional empowerment or central control?" European Policies Research Centre, No. 53, University of Strathclyde, March 2004, ISBN 1871130-59-X.

46 KAWECKA-WYRZYKOWSKA, Elżbieta, - "Financial Condition of Poland's Accession to the European Union.” In KAWECKA-WYRZYKOWSKA, Elżbieta; SYNOWIEC, Ewa. Poland and the European Union. Warsaw: Foreign Trade Research Institute, 2004.

47 European Commission (1998) 1998 Regular Report from the Commission on Slovenia's Progress Towards Accession, Brussels , p. 8

48 European Commission (1999) 1999 Regular Report from the Commission on Slovenia's Progress Towards Accession, Brussels , p. 59

49 European Commission (2003) 2003 Regular Report from the Commission on Romania's Progress Towards Accession", Brussels, p. 17

50 Idem
} 
decentralization in a transparent and stable manner" ${ }^{, 51}$. Decentralization and the need to clarify the allocation of responsibilities and the financial resources to the various levels of government remain points of interest and in 2005 the Commission emphasized that "the transfer of powers to local authorities is far from completion" and local financial autonomy "is still limited"52.

In 2006, the Report of the European institution limited itself to mention exclusively the state that regulatory efforts that had been made towards the decentralization without doing the usual references to consolidation ${ }^{53}$. "Progress has been made in the area of public administration reform. [...] Local Public Finance Law completes the legal framework of decentralization. Continue efforts to ensure the transfer of powers from the central level to the local one. Time schedules are developed and there are identified procedures that are necessary for the decentralization and resource management responsibilities, including financial ones" ${ }^{54}$.

Analysing these examples we can notice that the impulse for procedural regionalization and decentralization reached all countries from Central and Eastern Europe, at least in procedural terms. Firstly, there were created intermediate levels between central government and administrative structures. But even here there are many issues to be arisen given the fact that the map of the regions is not correlated with the upper structures of the sub-national levels of government. Except for Poland, regarding the others countries there is no correlation between the two territorial division, Bulgaria had 6 NUTS II regions and 28 regions at the upper level of the sub-national government; the Czech Republic had 8 NUTS II regions and 14 regions at the upper level of the sub-national government; Estonia, Latvia and Lithuania were regarded as single NUTS II regions, but they have respectively 15, 33 (26 districts plus 7 cities with districts right) and 10 regions at the upper level of the sub-national government; Hungary had recognised 7 NUTS II regions, but it had 41 regions at the upper levels of the sub-national government (19 counties plus 22 cities with county status plus Budapest); Romania had 8 NUTS II regions and 42 (41+ Bucharest) regions at the upper level of the subnational government; Slovenia was regarded as single NUTS II region (an attempt to constitute two regions of NUTS II status had failed, the two areas being too small to match

51 European Commission (2004) 2004 Regular Report from the Commission on Romania's Progress Towards Accession, Brussels , p. 18

52 European Commission (2005) 2005 Regular Report from the Commission on Romania's Progress Towards Accession, Brussels, pp. 8, 25

53 D. C Iancu, op.cit., p. 144

54 European Commission (2006) 2006 Regular Report from the Commission on Romania's Progress Towards Accession, Brussels, p. 39 
the NUTS criteria), and 58 regions at the upper level of the sub-national government; Slovakia has 4 NUTS II regions and 8 regions at the upper level of the sub-national government. Secondly, in all these countries there were given legislative packets in order to pave the way towards decentralization, stressing here reforms in Poland, Hungary and the Czech Republic.

Speaking from the perspective of functional regionalization and decentralization, the European Commission reports show that until the accession moment, no state revealed a normal functioning of the regional structures. However, there are notable differences. For instance, if Poland at the time of accession and in the next two years until the entry into financial cycle from 2007 to 2013, we can say that reached an optimal level of functional regionalization and decentralization, in the case of Bulgaria and Romania, the two countries registered "undeveloped regionalization and different decentralization" ${ }^{55}$. We cannot say that the two countries have reached a functional regionalization as stated Boullineau \& Suciu, but we agree that it is a result of a technocratic reflection that is necessary in order to facilitate the managements of the European funds ${ }^{56}$. Comparing the Central Eastern states, Slovakia, the Baltic states, Slovenia, Hungary and the Czech Republic were situated higher that the ywo aforementioned countries, the latter being the closest to the optimal decentralization of the country.

\section{Recentralization}

Going through the previous chapter, we can say that the process of Europeanization of the new EU member states from Central and Eastern Europe, seen through the regionalization and decentralization process, was a linear and solid trend. But, there were many elements which suggested that this process if not stopped, more regressed. Looking through a longer period time perspective (two decades-1994-2004), our opinion goes towards a process in which one can distinguish two periods: a period of evolution towards decentralization, conducted in the framework of EU accession (up in 2004/2007), followed by a period in which we can observe recentralization trends that become evident after 2007.

The process of "centralization" is analysed in our work through the following phenomena: unfinished or mimed decentralization; commission's ambiguities and vagueness in its own

55 BOULLINEAU, Emmanuelle; SUCIU, Marius op.cit., p. 357 
regionalist agenda and institutional adaptations; administrative restrictions that occurred during the economic crisis or the assertion of authoritarian trends regarding the assessment process of development of regional policies and programs.

\subsection{The unaccomplished decentralisation or formal decentralisation}

It has been observed that despite their intentions, the EU policies have not yet led to significant decentralization or the empowerment of regional actors in countries with highly centralised political systems ${ }^{57}$.

It is accurate to say that the current territorial map of the majority of Central and Eastern European countries is the result of a compromise not easily reached after intensive and passionate political debates involving conflicting interests and a variety of pressures, the European Commission being just one of them. ${ }^{58}$ The new territorial organisation came into effect bringing about an unprecedented modernization of the Central and Eastern European countries in terms of institutional and administrative systems. Some states succeeded in accomplishing successful regionalization projects. It can be argued that political, historical and cultural conceptions of Poland's regional framework have had at least as much to do with the shaping of the regional map of Poland as the pursuit of goal and principles set by the Commission with its conditionality criteria. Other states also developed their tasks, but after 2004 , or achieved "the limited level of decentralization froze" (the case of Hungary) ${ }^{59}$. Other states reached rather a shy development stage. For instance, in Romania the establishment of these eight regions assumes also the development of new institutions. In terms of effectiveness, their functions are being questioned taking into consideration the loose connections with the local level, fact that affects local authorities and central ones' ability to represent the needs and the interests of their citizens ${ }^{60}$. According to Boulineau \& Suciu "the regionalization is a formal process created for regions without power or territory" ${ }^{61}$. "They were created as cooperation forms with the sub-national territorial administrative forms: county in Romania (judet) sau in Bulgaria (oblast). They are led by Regional Development

57 MAREK Dan; BAUN J. Michael - "The EU as a Regional Actor: The Case of the Czech Republic", Journal of Common Market Studies Vol. 40, No. 5, 2002, p. 914.

58 KERLIN, J. - The Politics of Decentralization in Poland: Influences and Outcomes, Paper presented at the Annual Meeting of the American Political Science Association, San Francisco, 31 August 2001.

59 POGATSA, Z. op.cit., pp. 147-174.

60 HORGA, Ioan - „Romanian from Nation-State to Multilateral Governance.” In AMARAL, Carlos Pacheco (ed.) The Regional Autonomy and International Relations. Paris: L'Harmattan, 2011.

61 BOULINEAU, E.; SUCIU, M. op.cit., p. 357 
Council which does not have a legal personality and that is responsible for the distribution of European funds between the counties, after they were distributed at the central level ${ }^{62}$. We should add that neither the current Romanian administrative structure, composed of 42 counties, which is seen as a sufficient form suitable for the European the regional policy framework or for managing the structural funds after joining, is not functional, being too diffused $^{63}$. Additionally we can legitimately raise the question of the inability to influence the national strategies regarding the regions as it was demonstrated during 2000-2006 and 20072013.

The most recent report regarding Romania in what concerns the local and regional democracy dates from March 2011. The study report highlights the positive dynamics in Romania's development, but still draws attention towards the reforms that are needed due to the fact that there are no consultation mechanisms for the local authorities in subjects of their concern like financial and social aspects ${ }^{64}$.

In 2013 in Romania there could be noticed a pro-regionalization movement, as well as for decentralisation and preparation for the transformation of eight statistical regions into regional authorities that have their own rights. These new regions would to benefit from a large-scale transfer of competences from the central state, from the counties (județ) and from the municipalities. The exact details surrounding these new competences are not yet officially determined, but they will require revisions of the framework agreement on decentralisation and of the law on public administration. These regions are meant to enjoy a great deal of financial autonomy. The financing plan for local and regional authorities and the tax code should be modified accordingly, in a way that will also help the development of local selfgovernment. The existence of these new regional entities may also trigger the restructuring of services and changes in the number of civil servants. It is also worth noting that the presidents of these new regions are proposed to be elected by direct vote ${ }^{65}$. Unfortunately this process is

\section{Idem}

63 SUCIU, Marius - „Decentralization and regional development in Romania. An unfinished reform in search of a "European" model." In PALERMO, Francesco; PAROLARI, Sara - Regional Dynamics in Central and Eastern Europe New Approaches to Decentralization. S.l. Brill Online, 2013 pp. 103-146.

64 Adina Răducanu, "Europe of or With Regions: Regionalism in Romania", Journal of Public Administration, Finance and Law, Issue 3/2013, accessed on September 23, 2013, http://www.jopafl.com/uploads/issue3/EUROPE_OF_OR_WITH_REGIONS_REGIONALISM_IN_ROMANIA .pdf.p.48

65 The Council of European Municipalities and Regions (CEMR), Descentralisation at crossroade. Terirtorial reforms in Europe in times of crisis, october 2013, accesed on 18 Noveber 2014, http://www.ccre.org/img/uploads/piecesjointe/filename/CCRE_broch_EN_complete_low.pdf 
greatly underdeveloped, apart from a few progress realized by the agglomeration of some decentralized institutions (health, finance, construction inspection, inspection of the forest), in the 8 centres of NUTS II nothing was achieved. There is rather the perception that these agglomerations are nothing more than some recentralization masked result of the financial crisis. But looking from another perspective, in the case of Romania, and other countries from the region, the after-crisis effects can constitute the engine for the creation of functional regions, because the major plans to reduce costs and improve public administration efficiency may, however, affect the traditional (judetele) organisation of local and regional authorities in Romania in the favour of regions.

To bring forward an argument in support to this assumption we can refer to the task of setting territorial boundaries for the new sub-national governmental institutions. As previously observed, one of the prime requirements of the acquis is the establishment of regional units with dimensions matching the NUTS II classification and capacities to manage EU funds. At least four divergent positions supported by different cultural and political beliefs struggled to obtain a legal acknowledgment of their own standpoint on the country's internal boundaries. The result of the compromise was a solution in compliance with the NUTS II classification characterised in the case of Poland by a marked mismatch between the administrative boundaries and the country's socio-economic regional profile, a solution which is much more likely to complicate rather than facilitating the reduction of internal disparities ${ }^{66}$. Also in Poland the powiat has become largely dependent on the regional level, which is responsible for making the final decisions on the allocation of EU structural funds ${ }^{67}$.

In case of Romania the boundaries of these regions have been established. The 8 units NUTS II which were created in Romania have in few cases (except the South-West and partially the North-East regions) a functional socio-economic regional profile ${ }^{68}$. The two examples of Poland and Romania, are, in our opinion, the two large regionalism models from Central and Eastern Europe. In the Case of Poland we can discuss about a system of regional decentralisation $^{69}$, whereas in the case of Romania we can notice a model of regionalised

66 For a broader discussion on this issue see ROKITA, Jan - Continuity and Change in Polish Policy after Regional Reform in 1998, Paper presented at the Conference "Regionalisation of Polish Politics" SSEES, 15-16 April 2002.

67 BERTRANA, Xavier; HEINELT, Hubert - The Second Tier of Local Government in the Context of European Multi-Level Government Systems. In Revista catalana de dret públic, 46, 2013, pp. 73-89.

68 HORGA, op. cit., p. 287-288

MARCOU, Gerard - Between Economic Integration and Institutional Change: Models and Questions. In Local Government Brief, March 2001. 
unitarism $^{70}$.

The new regional authorities were given a wide range of competences and responsibilities for conducting regional development policies. When drawing up the reform the central governments have secured certain strategic dispositions allowing them to preserve a significant degree of control over regions. If the regional institutions have theoretically responsibilities in the field of programming regional economic development, their activities are subordinated to the control of a government-appointed entity. For instance, the Wojewoda which represents the central government in Poland or Prefectul in the caze of Romania ${ }^{71}$ are designed to safeguard state's interests not only by controlling the legality of the decisions that are taken by the elected regional authorities, but also by making certain that they are in line with the priorities defined at the national level. Moreover, what is even more important to note, being the representatives of the state treasury they also perform a financial control at the sub national level.

The decentralisation of competences has not been followed with an adequate degree of financial decentralisation. The regions still remain to a large extent financially dependent on the central government, and this fact poses severe restrictions to regional authorities when elaborating their own strategies of local development, hence it contradicts their statutory functions. As a result the Ministries of Finance with the power to provide specific grants and subsides to sub-national authorities exercise a significant control over their functions in all Central Eastern European countries. The dominant position of the centre over the regions in terms of finance undermines the validity of the regional contract as a symbol of a new, regionalised approach to regional policy-making.

Another example is that the central government still clearly possess the upper hand in fields like the regional development which has increasingly become a major element of European domestic policy. The latter should not be surprising, since the sub-national authorities are playing a leading role in the regional programming within the EU Cohesion policy framework. It has been until now the exception rather than the rule. As it has been previously noted, these implications are strictly connected with the vagueness and the ambiguities of the EU Commission's recommendations, which contribute to the paradoxical outcome of the territorial reforms from Central and Eastern European countries. Therefore, we can observe an apparent empowerment of regions which hides a de facto re-centralisation

70 SHERPEREEL, J.A. - "Sub-National Authorities in the EU's Post-Socialist States: Joining the Multi-Level Polity?” In European Integration, Vol. 29, No. 1, 2007, p. 41. 
of power with the government controlling the purse strings.

Concluding, the regionalization and decentralization process from Central Eastern states has led towards three major evolutions. Firstly, the new sub-national governments have been granted with increasing competences for regional development in the majority of the states. Secondly, within all countries we can notice a centralisation of procedures; the lack of coordination between different levels, as a consequence of an unclear division of competences does represent a serious problem. Finally, there are severe constraints that block the efficient implementation of the EU's co-financed programmes which, as widely known, require the complementary participation of authorities from all administrative levels.

If during the 2000-2006 financial cycle, these developments have affected more than the relationship between Central and Eastern European countries and Brussels due to the low volume of funds to which they had access, during 2006-2013 financial cycle, in which the states of the region had access to over $70 \%$ of cohesion funding, contradictory developments in decentralization and local and regional autonomy determine a relationship between these states and Brussels that paradoxically will be translated through making regional policy without regions.

\subsection{Central administrative structures have to be consolidated in order to develop a} solid capacity for the absorption of Community funds ${ }^{72}$

Having been conceived within a regional dimension, the EU cohesion policy brought for the first time into the EU vocabulary notions such as partnership, subsidiarity and decentralisation. These concepts have been cultivated by the European Commission since the first reform of Structural Funds on order to foster innovative strategies and to promote more decentralised approaches to take place in regional policy formulation and implementation.

Throughout the 90s, the "Europe of the Regions" vision has been moving in parallel with the gradual integration of Central Eastern countries, which were encouraged to develope decentralised regional development policies according to the partnership principle, as well as to establish autonomous sub-national administrative bodies and possibly also political authorities which would implement the Structural and Cohesion Funds programmes. However, as noted by a number of scholars, for various reasons, from the late 90s onwards,

72 See Michel Barnier, ex Commissioner for Regional Policy and Institutional Reform (2000-2004), in a interview 26 March 2001, http://europa.eu.int/comm/regional_policy/debate/chat7_en.htm . 
Commission's own regionalist agenda started to be affected by ambiguities, vagueness ${ }^{73}$ and "presion adaptative" ${ }^{, 74}$. In particular, Commission has begun to stress a clear preference for the centralised management of the Community assistance. ${ }^{75}$ This shift in orientation towards the regionalisation issues was originally connected to the doubts about the practicability, in these countries, of defining and coordinating tasks and responsibilities of all bodies and institutions which would be involved in the preparation and implementation of programme funds in Central and Eastern European countries. In principle the European Commission was first and foremost interested in the fact that the new Member State should ensure a reliable absorption capacity, which, as a prerequisite, asks for the efficient consolidation of the central administration. ${ }^{76}$ Putting it differently, on one hand, the Commission proved not to be willingly to deal with centralised states in which regional levels are largely subordinated to the central government, while, on the other hand, the adoption of the acquis, the implementation, the efficient use of pre-accession funding in light of a trustworthy management of Structural and Cohesion funds, seem to demand the strengthening of the upper level of government.

It might be upheld that such an approach is the consequence of the fact that the European Commission has not a regionalism model to propose. More specifically, with regard to the creation of the sub-national institutions that are essential for the administration of the regional aid funds, several ambiguities arise in terms of whether these should be governmental or purely administrative. Considering that there is no provision within the treaties, neither within the secondary legislation, it cannot be interpreted as stipulating a specific type of territorial organisation. It is not even entitled within the law to take a position on this issue ${ }^{77}$. Apart from the latter, the ambiguous position of the European Commission between centralisation and regionalisation in the Central and Eastern European countries largely influenced the final shape of the territorial reform in these countries.

This centralised decision-making structure largely reflects all the ambiguities implicitly included in the concept of partnership, by far the most frequently quoted, and, at

73 D. Marek \& J.M. Baun, op. Cit., pp. 895-919.

74 BAFOIL, Francois, - Europe centrale et orientale. Mondialisation, européanisation et changement social, Paris : Les Presses de Science Po, coll. «Références Monde », 2006.

75 FERRY, Martin, - "The EU and recent regional reform in Poland." In Europe-Asia Studies, Vol. 55, No. 7, 2003, pp. 1097-1116.

76 Michel Barnier, op.cit, loc.cit..

77 MARCOU, Gérard - «L'adaptation des structures territoriales face à la politique régionale communautaire ». Revue d'études comparatives Est-Ouest, 2002, vol. 32, n 3, p. 131-167. 
the same time, the vaguest one among the principles governing the overall functioning of the EU Cohesion policy. This principle basically insists on a close cooperation between the European Commission, Member States, competent body of governmental and selfgovernmental administration and other public bodies.

It is indeed widely recognised that the active participation and cooperation of various actors is a sine qua non condition for the success of regional development. The application of such principle, however, is completely left to Member States' own discretion and the European Commission has constantly proved to be not in the position to control that they do so in practice. Moreover, observation of the legal dispositions governing the Structural funds' implementation reveals that the Commission is not even entitled by the law to force Member States to apply the partnership principle in compliance with the rules set out at EU level since the Structural Fund Regulation carefully avoids requesting the Member States to change any existing ways of involving sub national authorities and interest organizations ${ }^{78}$.

An investigation of the implementation of partnership principle within the Central and Eastern European countries' approach towards the implementation of the EU co-financed programmes leads to unclear conclusions. Undoubtedly, the introduction of EU decisionmaking practices has brought about positive adjustments with proliferation of partnerships as well as noticeable mobilisation of regional actors cultivating new relationships and establishing networks potentially advantageous for regional development. Nevertheless, regional self-governments, just like the central governments, seem to have taken advantage of the opportunity offered by the imprecision of the EU prescriptions to favour their own interests and given preference to the participation of certain actors from the private sector at the expense of representatives from the civil society. Consequently, despite certain mobilisation of NGOs around the Structural Funds, the latter so far have not contributed to the reinforcement of the civil society in any significant way. It has been frequently observed that application of the partnership principle vary widely within the EU according to the institutional structure of each Member State. However, as long as the EU's regulations let Member States decide whether, and if so to what extent they implement the EU co-financed programmes in accordance with the partnership principle, any expectation to change the status quo will be nothing more than futile. Subsequently, it should not be surprising if Central and Eastern European countries, in general, are regarded as the most disappointing

78 According to art. 11 Council Regulation (EC) No. 1083/06 "each Member State shall organise a partnership where appropriate and in accordance with current national rules and practices". 
EU Member States in terms of involvement of public and private sub-national actors in both the formulation and implementation of the EU Cohesion policy. Consequently, following the model of certain Western EU big recipients of Structural Funds the EU funds' implementation system in Poland until now has been highly centralised. ${ }^{79}$ Propensity to concentrate the management of the EU funds in the hands of few Ministries resulted from decades of administrative centralism and distrust of self-governments located at lower administrative levels. It can be argued that these tendencies have been even reinforced by the Commission's attitude towards sub-national authorities. In fact, the latter has always demonstrated to be reluctant in accepting programming at a regional level for the structural funds being afraid of the sub-national insufficient administrative capacity.

Moreover, the early system of pre-accession assistance was not meant to be implemented at a regional level. The regulation of June 1999 on pre-accession funds does not call for decentralised management of programmes co-financed by ISPA and SAPARD funds, only the PHARE Regulation being disposed to contemplate for progressively decentralised programmes that were to be put in place once conditions would make it possible. The situation did not change after the accession, thus, when negotiating the structural intervention under the 2004-2006 framework, the European Commission, given the relatively short time, showed its eagerness to accept only one regional and centrally controlled operational programme, instead of 16 different ones to be fully managed by sub-national authorities. ${ }^{80}$ To bring forward arguments in support to this suspicion, it may be referred to the new philosophy inspiring the latest reform of the Structural and Cohesion Funds. One of the main purposes of the fourth reform of the EU Cohesion policy was actually to further decentralisation and programming procedures simplification through a clearer separation of tasks and competencies between the European Commission and the Member States. According to Council Regulation (EC) No. 1083/06 the Commission is basically responsible for the coordination and control of the structural assistance in conformity with the priorities and the objectives of the EU. In other words, with the latest reform of Structural and Cohesion Funds

\footnotetext{
79 Therefore even though there was a shift in emphasis and approach with regard to the regions' role, the member states have always been in full control of territorial assets so that in three of the four original "cohesion countries" a policy that was regional by name would become predominantly a national policy See George Andreou, "EU Cohesion Policy in Greece: Patterns of Governance and Europeanization", in South European Society and Politics, Vol. 11, No. 2, 2006, pp. 54-79.

80 MARCOU, Gerard - "Regionalisation for Development and Accession to the European Union: a Comparative Perspective." In G. Marcou Regionalization for Development and Accession to the European Union: A Comparative Perspective, LGI Fellowship Series, 2002, pp. 11-25.
} 
the Cohesion policy's programming has been significantly modified in the sense that Member States with the new practice based on the NSRF have granted much more autonomy in determining the final allocation of funds among different operational programmes, sectors and areas of intervention.

Regional authorities, in particular those belonging to the new Member States, articulated several concerns arguing that further decentralisation of the EU Regional policy might conduct to nothing but to the re-nationalisation of the Regional policy, since there were no binding rules at EU level precluding central governments from monopolising the structural funds' realisation ${ }^{81}$. Having endowed Member States with more responsibilities regarding the implementation of the EU regional policy without having provided the partnership principle with any significant enhancement and more generally without having granted the Commission with any meaningful power to have control over the Member States simply makes for both the Commission and sub-national authorities impossible to challenge the hegemony of the state executive. Consequently a high concentrated management of the EU co-financed programmes at the upper institutional level at the expense of the role of sub-national authorities will be sensibly unavoidable. Even the Operational Programmes that are to be implemented at regional level would remain an empty shell if regional or sub-national authorities remained embedded in centralised territorial organisation systems. The influence of sub-national actors in the individual Member States confirms that this is mostly determined by existing systems of territorial relations, and not a process of requirements in the EU cohesion policy.

To sum up, undeniably the European Commission through its regional policy has been an important driving force regarding the process of territorial decentralisation in Central and Eastern European countries. However, this influence has generated different outcomes. There is little question about the fact that the imposition of the Cohesion policy framework has pushed the regional authorities to adjust their practices in what regards the management of regional development policy. It is out of doubt that the position of sub-national authorities within the national institutional structure, if weighted against that existing during the communist system, has been largely reinforced. However, the ambiguity of the Commission's own regionalist agenda regarding the territorial and administrative reforms along with its

81 Another signal of decentralization of implementation of EU Cohesion policy in favour of Member States is the inclusion of the Communitarian Initiatives (CIs) and Innovative Actions (IAs) into the Operational Programmes. In the previous three programming period the Commission used to reserve $10 \%$ of Cohesion policy's global allocation outside the priority objectives for the promotion of sectoral action. It was widely recognised that the Commission enjoyed much more power over these specific actions than the various objectives. 
reluctance to allow the regions to formulate and manage regional operational programmes, have given the central government the opportunity to impose solutions suiting its own interest and have made the re-centralisation of power much easier.

Therefore, we can say the EU regional policy model that was developed in order to manage the Structural Funds has provided incentives for the mobilisation of local and regional interests in Central and Eastern Europe. However, the strength and impact of empowerment depends on whether local or regional interest groups existed as organised political actors rooted in the regional communities or identities, and whether they formed broader proregional advocacy coalitions with other political actors and participated in government ${ }^{82}$.

\subsection{The administrative coercions that developed within the economic crisis and} authoritarian trends frameworks

The general movement of decentralisation initiated before the crisis has been jeopardised in some countries by the centralising tendencies of the state. Such reforms are now linked more to the goal of achieving greater economies amidst a climate of austerity and public expenditure cutting. They may also serve as means for the states to regain political control from the powers that were delegated to local and regional authorities (for example, Hungary, where water distribution is now to be managed by a governmental agency) $)^{83}$.

This recentralisation trend can also occur by ways of a loss of competences for the smaller authorities in favour of the larger ones. In the Czech Republic there has decreed that many services for citizens are only to be managed by the larger local authorities. Lastly, the law in Hungary requires municipalities to group their services together in order to be able to close the municipal offices of the smaller municipalities, while maintaining their political and administrative existence. While there is no guarantee that a strict control over costs will be achieved by opting to proceed in this way. These efforts are also hazardous for local selfgovernments since they impose new regulations without any prior consultation. They also have weakened the ties of proximity established between the citizens and local authorities ${ }^{84}$. The territorial reforms implemented in recent years also tend to consist of mergers between

82 BRUSIS, Martin - „European Union incentives and regional interest representation in Central and East European countries", in Acta Politica 45, 70-89 (April 2010) I doi:10.1057/ap.2009.31

83 The Council of European Municipalities and Regions (CEMR), Descentralisation at crossroade. Terirtorial reforms in Europe in times of crisis, october 2013, accesed on 18 Noveber 2014, p. 10 http://www.ccre.org/img/uploads/piecesjointe/filename/CCRE_broch_EN_complete_low.pdf 84 idem 
authorities at local or regional level. This too may pose a risk for local self-government if the local governments and populations concerned are not properly consulted on the matter beforehand.

In Bulgaria, the government has imposed stricter rules for budget management and increased the dependence of the municipal and regional authorities' budgetary process on the financial ministry's by-laws. In addition to stricter budget controls, a law on public finance has reduced the level of indebtedness that the municipalities can attain to $15 \%$ of revenue (compared to $25 \%$ ). The government also requested a $15 \%$ reduction in the number of local civil servants from each municipality. The financial transfers from the central level were frozen since 2009 (except the general equalising subsidy and the transfers for education) and generally have not been reviewed to take inflation into account. Lastly, a change in the electoral laws in 2011 brought new conditions: local mayors should be elected for settlements of more than 350 inhabitants (previously more than 150); borough mayors in the three biggest municipalities (capital Sofia, Plovdiv and Burgas) should be elected not by a direct vote but by the municipal councils. A $50 \%$ decrease in the remuneration of municipal councillors was imposed by legal changes ${ }^{85}$.

Among the reforms adopted in reaction to the economic financial crisis, the central government has reduced the share of public expenses at the municipal level. As a result of greatly reduced municipal revenues and practically frozen financial transfers to local authorities, the financial autonomy of local authorities in Bulgaria faces strong difficulties. Nonetheless, a change in legislation concerning the protection of municipal powers could guarantee a certain level of political autonomy for Bulgarian municipalities ${ }^{86}$.

Public administration reforms drafted by the Czech Republic government in 20112012 have not been approved. The local government association strongly disagreed with the draft proposals and aimed to start further negotiations with the government on a new shape of the reforms. The reform, which should been entered into force partially in 2014 and entirely in 2016 , calls for the re-concentration of certain delegated competences in favour of designated municipalities, of which there are 205 in the country out of a total of 6249 . These municipalities will be the sole contacts for handling the competences relating to the environment, civil status, construction and school reforms. Regular municipalities will only be responsible for competences that are strictly local. At the same time, new financing 
methods are being considered, mainly to take new municipal competences into account. These reforms will also have an impact on the organisation of certain municipal services, which will be merged together with those of several other municipalities. Programmes to improve public administration efficiency, led by these new larger municipalities, have also been set up ${ }^{87}$.

Even though the European Charter of Local Self-Government seems to be respected, the reforms emerging from the crisis, along with the austerity measures, may negatively impact the smallest municipalities. Local public services run the risk of becoming too distant from the citizens, which may raise a number of problems, particularly in the country's rural zones $^{88}$.

The government of Hungary has adopted a series of measures, mostly aimed at recentralising competences and keeping a closer watch over local activities. From 2010 onward, Hungary took a sharp U-turn toward recentralization. The radical shift of power in Hungary can be understood as a response to the failure of the neoliberal model of economic development $^{89}$. The 175 old administrative districts representing the state, abolished in 1984 (járás), were re-established in 1 January 2013 and were charged with managing certain public services as well as carrying out administrative supervision of local authorities. At the same time, county councils were divested of some of their competences, for example the management of public institutions such as secondary schools, hospitals, social centres, cultural centres or museums. However, they did acquire competences relating to spatial planning and territorial development. Municipalities with less than 3000 inhabitants were affected by the reforms as well, and were also stripped of the right to manage most public institutions. Certain legislative provisions also address inter-municipal associations. Even if all member municipalities retain their legal existence, local authorities of less than 2000 inhabitants must close their municipal offices and join with others in order to form a group. Moreover, water management agencies can now only provide services to populations made up of at least 50000 people $\mathrm{e}^{90}$.

The report of the Congress of Local and Regional Authorities on from 31 October 2013 welcomed Hungary's ratification of the Additional Protocol to the European Charter of Local Self-Government on the right to participate in the affairs of a local authority in June

87 Ibidem, p. 27

88 Idem

89 POGATSA, Z. op.cit., pp. 147-174.

90 The Council of European Municipalities and Regions (CEMR), Descentralisation at crossroade. Territorial reforms in Europe in times of crisis, october 2013, accesed on 18 Noveber 2014, p. 36 http://www.ccre.org/img/uploads/piecesjointe/filename/CCRE_broch_EN_complete_low.pdf 
2010. But, it expressed regret, however, that this positive step was overshadowed by the recent reforms, which led to a deterioration of the legislative framework on local and regional issues. In particular the report underlined a deep concern about the overall trend towards recentralisation of competences and the weak level of protection afforded, at constitutional level, to the principle of local self-government. It also underlined the fact that the local authorities in Hungary remain strongly dependent on government grants, and that the consultation procedure needs reinforcement, bringing it in line with Charter provisions on timely and appropriate consultation practices. Lastly, local authorities did not have an effective judicial protection as regards their right of recourse to courts to guarantee their rights under the Charter ${ }^{91}$. The Congress of Local and Regional Authorities recommended notably that the Hungarian authorities take steps to guarantee the implementation of the principle of self-government and the financial autonomy of local and regional authorities as set out in the Charter. The recommendation also strongly encourages the Hungarian authorities to clearly define the competences of local and regional authorities and to seek solutions which will provide local and regional authorities with the requisite human and material resources. It calls on the Hungarian Government to put in place an effective consultation procedure for all matters which concern territorial authorities directly as stipulated by the Charter, and to implement effective remedies which provide a right for representatives of local authorities to lodge a complaint to courts in order to protect their rights laid down in the Charter ${ }^{92}$.

Political discussions are underway in Poland envisaging to increase local autonomy and flexibility of organisation of some services. These changes should help to increase efficiency and reduce costs, as well as to introduce fiscal incentives or voluntary amalgamations of municipalities. The envisaged changes do not modify the overall structure of the territorial organisation in Poland, but would enhance the autonomy and flexibility of local governments. A draft amendment on the reform of local public finance was proposed by the national association of cities with the support of 300000 citizens' signatures, but the national government expressed its disagreement for the proposal.

Another debate concerns the organisation of metropolitan areas, with many contributions calling for special governance arrangements around several major urban centres

\footnotetext{
91 Report Congress of Local and Regional Authorities, Local and regional democracy in Hungary, Strasbourg 31 october 2013, p. 1, accessed on 21 Novenber 2014 https://wcd.coe.int/ViewDoc.jsp?Ref=CG(25)7PROV\&Language=lanEnglish \&Ver=original \&Site=COE\&Back ColorInternet=C3C3C3\&BackColorIntranet=CACC9A\&BackColorLogged=EFEA9C 92 Idem
} 
in the country, where 65 cities already exercise the powers otherwise vested in the second-tier level (powiat) of local government. Bottom-up arrangements have taken place in response to a dismissed draft act on metropolitan areas, with the creation in 2007 of the Upper Silesian Metropolitan Union, joined by 14 cities with county-level powers, concerning over two million inhabitants in total, or with the signature in the same year of the Tricity Charter on cooperation between three urban areas at the Baltic coast. Lastly, the competences of Polish regions are to be strengthened under a 2009 law.

While the financial autonomy of the Polish local and regional authorities has been undermined as a result of the crisis and austerity measures, the proposed draft amendment could reinforce this autonomy. The European Charter of Local Self-Government, ratified without reservations, seems to be well adhered to in the country ${ }^{93}$.

Romania presents itself with particular features because the Romanian state has not yet implemented the regions. Judete are the main 'intermediate level' between the municipalities and the national government in a highly centralised country where the second tier of local government is subject to relatively rigid expediency controls in a local democracy greatly influenced by more than a century of centralist tradition ${ }^{94}$.

The decentralisation processes and the democratic reforms (for example, the introduction of directly elected presidents of the judete in 2008) seem to empower the second level of local self-government but, at the same time, the growth of earmarked grants, the 'burden of administrative responsibilities ${ }^{95}$ still fulfilled by the judete and the aforementioned expediency controls result in major constraints and challenges for local autonomy ${ }^{96}$. After 2009 this process deepened even more through the accession of their dependence towards the government.

In Slovenia, in 2012 and 2013, massive interferences in the legislation regarding local self-governments financing were attempted. Lump sum amounts for the year 2013 and 2014 were decreased by more than $10 \%$. Recently the government proposed a law on financing the Municipalities, which breaches the principles of the European Charter of Local SelfGovernment and the recommendations of the Council of the EU in terms of budget management. Law on real estate tax could cause great damage to the financial sufficiency of

93 Ibidem, p. 48

94 BERTRANA, Xavier; HEINELT, Hubert op. Cit, p. 78

95 STANUS, Cristina; POP, Daniel - 'Romania.' In: Hubert Heinet, Hubert; Xavier Bertrana (eds.). The Second Tier of Local Government in Europe. Provinces, counties, départements and Landkreisein comparison. Abingdon \& NewYork: Routledge, 2011, pp. 205-223. 96 Idem 
local self-government. It critically encroaches upon the right of municipalities to have the real estate tax as their own revenues with the constraint to share it by half with the central government. The act will enter into force in the beginning of 2014.

At the same time, a proposal of the national territorial organisation, without consulting the municipalities or the representative organisations, was presented to the public, introducing the concept of eliminating all municipalities with less than 5000 inhabitants with the clear premise of supposed moneysaving. After harsh critique, it was postponed until 2018. The 2006 Constitutional amendments in the area of local self-government will enable Slovenia to get a two tiered self-government. After years of professional and political debates, the model which already prevails strongly in most European countries is considered. A visit by the Council of Europe's Congress of Local and Regional Authorities in 2011 highlighted how important the creation of regions is in Slovenia. Today, in spite of several attempts, there is still no agreement on the number of regions or their particular competences. The establishment of the regions is postponed due to the lack of political will. The European Charter of Local Self- Government seems to be well known, during the crisis, it is less respected by the country. The mission representing the Congress of Local and Regional Authorities pointed out the frailty of local authorities' autonomy and the need to create true regions in Slovenia ${ }^{97}$.

Thus, we can emphasize several factors that led throughout 5-6 years to the emergence of a centrifugal phenomenon against decentralization- re-centralization in Central and Eastern countries $^{98}$ : firstly, the need to control the distribution of scarce resources during a transformational recession or outright crisis; secondly, the need to control economic and social differences among territorial units, so as to prevent the marginalization of some regions and the resulting social and political tensions that would endanger the new regime; lastly, the

97 Ibidem, p. 53

98G. Gorzelak identified six myths about local government in the post-socialist countries that contributed to false expectations, that can be applied to the re-centralization process (1) the myth of local autonomy (unrealistic expectations toward the potential of local autonomy and the rejection of any central involvement in local affairs); (2) the myth of prosperity (the belief that economic autarky will guarantee the prosperity of local communities); (3) the myth of property (the belief that the restoration of municipal property will in itself guarantee local development); (4) the myth of omnipotence (the belief that municipalities are both entitled to and capable of deciding all local problems by themselves); (5) the myth of eagerness (the belief that zeal can compensate for knowledge and skills in local politics and administration); and (6) the myth of stabilization (the belief that stable conditions are what local governments should and can attempt to reach). G. Gorzelak, "Myths on local self-government in post-socialist countries", in Changing territorial administration in Czechoslovakia: International viewpoints, edited by P. Dostál, M. Illner, J. Kára, and M. Barlow. Amsterdam: University of Amsterdam, Charles University, and the Czechoslovak Academy of Sciences, 1992 . apud M. Illner, op. cit., p. 27 
need to formulate policies aimed at maintaining national integration in a general atmosphere of societal fragmentation, resulting from the transformation processes. Nevertheless, certain governmental actions run counter to the principle of subsidiarity. Moreover, they often seem to result in the recentralisation of competences, the forsaking of the proximity of local governments to the citizens as a result of new territorial organisations and in extensive budgetary and operational restrictions ${ }^{99}$.

These developments from Central and Eastern Europe were not foreign to the affirmation of the European construction process. Even before the economic and financial crisis erupted, but still amplified it, it is what Jurgen Habermas has called the "supranatinal paternalism" 100 , which trained, we argue, through mimicry the re-centralization phenomenon in EU member states from Central and Eastern Europe.

Only the continuation of the European integration process as a "supranational democracy" 101 could continue the process of decentralization in Central and Eastern Europe.

There are signs that show the fact that the financial, economic and social crisis has not remodelled the overall architecture of local and regional authorities in Europe. It has nevertheless had a major impact on Europe's approach to the organisation of services and the question of financial independence. The territorial reforms currently underway seem to take into account the desire for greater decentralisation and the principle of subsidiarity advocated by the European Union and the Council of Europe.

\section{Bibliography}

Council of European Municipalities and Regions (CEMR) - Descentralisation at crossroade. Terirtorial reforms in Europe in times of crisis, October 2013, [18 Noveber 2014], http://www.ccre.org/img/uploads/piecesjointe/filename/CCRE_broch_EN_complete.

European Commission - "1998-2003 Regular Reports from the Commission on Czech Republik's Progress Towards Accession”, Brussels, 1998-2003.

99 The Council of European Municipalities and Regions (CEMR), Descentralisation at crossroade. Terirtorial reforms in Europe in times of crisis, october 2013, accesed on 18 Noveber 2014, p. 18 http://www.ccre.org/img/uploads/piecesjointe/filename/CCRE_broch_EN_complete_low.pdf

100 HABERMAS, Jurgen - „Europe, Hunagry and the Transnational Democracy.” In European Comission, The Mind and Body of Europe: a New Narrative, European Institut, 2014, pp. 178-186.

See also HABERMAS, Jurgen, Fur ein starkes Europe-Aber was heisst das? Blatter fur deutsche und international Politik, vol. 3, 2014, pp. 85-94.

101 Ibidem. p. 186. 
European Commission - "1998, 2001-2003 Regular Reports from the Commission on Hungary’s Progress Towards Accession”, Brussels 1998, 2001-2003.

European Commission - "2004-2006 Regular Reports from the Commission on Bulgaria's Progress Towards Accession”, Brussels, 2004-2006.

European Commission - “1999 -2003 Regular Reports from the Commission on Poland's Progress Towards Accession”, Brussels, 1999-2003.

European Commission - “2003-2006 Regular Report from the Commission on Romania's Progress Towards Accession”, Brusselles 2003-2006.

European Commission - "2000-2003 Regular Report from the Commission on Slovak Republik's Progress Towards Accession”, Brussels 2000-2003.

European Commission - “1998-1999 Regular Report from the Commission on Slovenia's Progress Towards Accession”, Brussels 1998-1999.

Report Congress of Local and Regional Authorities, Local and regional democracy in Hungary, Strasbourg 31 october 2013. [21 November 2014] https://wcd.coe.int/ViewDoc.jsp?Ref=CG(25)7PROV\&Language=lanEnglish\&Ver=original $\&$ Site $=$ COE $\&$ BackColorInternet=C3C3C3\&BackColorIntranet=CACC9A\&BackColorLogge $\mathrm{d}=$ EFEA9C

ANDREOU, George - "EU Cohesion Policy in Greece: Patterns of Governance and Europeanization“, in South European Society and Politics, Vol. 11, No. 2, 2006, pp. 54-79.

BAFOIL, Francois, - Europe centrale et orientale. Mondialisation, européanisation et changement social, Paris : Les Presses de Science Po, coll. «Références Monde », 2006.

BARNIER, Michel, - A interview from 26 March 2001, http://europa.eu.int/comm/regional_policy/debate/chat7_en.htm. 
BERTRANA, Xavier; HEINELT, Hubert - The Second Tier of Local Government in the Context of European Multi-Level Government Systems. In Revista catalana de dret públic, 46, 2013, pp. 73-89.

BOULLINEAU, Emmanuelle; SUCIU, Marius - "Décentralisation et régionalisation en Bulgarie et en Roumanie. Les ambiguïtés de l'européanisation”. In L'éspace geographique, 2008, vol. 37, p. 349-363.

BOUCKAERT, Geert - "Public Sector Reform in Central and Eastern Europe". Halduskultuur, 2009, vol 10, pp. 94-104.

BOUCKAERT, Geert - "Cultural Characteristics from Public Management Reforms Worldwide.” In SCHEDLER, Kuno; PRÖLLER, Isabella (eds). Cultural Aspects of Public Management Reforms. Amsterdam: Elsevier, 2007, pp. 29-64.

ELANDER, I. - "Between centralism and localism: On the development of local selfgovernment in post-socialist Europe". Paper presented at conference, Democratization and Decentralization: Four Years of Local Transformation in Central and Eastern Europe, Krakow, 2-6 August, 1995.

FERRY, Martin, - "The EU and recent regional reform in Poland." In Europe-Asia Studies, Vol. 55, No. 7, 2003, pp. 1097-1116.

FERRY, Martin - "Regional Policy in Poland on the eve of EU membership: regional empowerment or central control?" European Policies Research Centre, No. 53, University of Strathclyde, March 2004, ISBN 1-871130-59-X.

DABROWSKI, Marek - Implementing Structural Funds in Poland: Institutional Change and Participation of the Civil Society, Paper presented at the Conference Central and Eastern European Engagement, AESOP YA Meeting, Bratislava, 2007. 
GLOWACKI, Viktor - „Regionalization in Poland”, in Gérard Marcou, Regionalization for Development and Accession to the EU: A Comparative Perspective. Budapest: The Local Government and Public Reform Initiative, 2002, pp. 105-137.

GORZELAK, G. - "Myths on local self-government in post-socialist countries." In Changing territorial administration in Czechoslovakia: International viewpoints, edited by P. Dostál, M. Illner, J. Kára, and M. Barlow. Amsterdam: University of Amsterdam, Charles University, and the Czechoslovak Academy of Sciences, 1992.

HABERMAS, Jurgen - „Europe, Hunagry and the Transnational Democracy.” In European Comission, The Mind and Body of Europe: a New Narrative, European Institut, 2014, pp. 178-186.

HABERMAS, Jurgen, Fur ein starkes Europe-Aber was heisst das? Blatter fur deutsche und international Politik, vol. 3, 2014, pp. 85-94.

HORGA, Ioan - „Romanian from Nation-State to Multilateral Governance.” In AMARAL, Carlos Pacheco (ed.) The Regional Autonomy and International Relations. Paris: L’Harmattan, 2011.

HORGA, Ioan; BARBULESCU, Iordan Gh; IVAN, Adrian et al. - Regional and Cohesion Policy. Insights intoof the Partership Principle in the New Policy Design. Debrecen: University Press \& Oradea University Press, 2011.

Hughes, James, SASSE; Gwendolyn; GORDON, Claire E - „EU enlargement, Europeanisation and the dynamics of regionalisation in the CEECs." In KEATING, Michael; HUGHES, James (eds.) The Regional Challenge in Central and Eastern Europe: Territorial Restructuring and European Integration. Regionalism \& federalism (vol. 1). Brussels, Peter Lang, 2003.

HUGHES, James; GWENDOLYN, Sasse; GORDON, Claire - Europeanization and regionalization in the EU's enlargement to Central and Eastern Europe: the myth of conditionality. Basingstoke: Palgrave, 2004. 
HUGHES, James; GWENDOLYN, Sasse; GORDON, Claire - Conditionality and compliance in the EU's eastward enlargement: regional policy and the reform of sub-national governance. In Journal of Common Market Studies, 42 (3). 2004, pp. 523-551.

IANCU, Diana - Camelia, Uniunea Europeana si Administratia Publica. Iasi: Polirom, 2010.

ILLNER, Milka - „The Territorial Dimension of Public Administration Reforms in EastCentral Europe,", in Polish Sociological Review , vol. 1., no. 117 [1997]:, pp. 23-45.

KERLIN, J. - The Politics of Decentralization in Poland: Influences and Outcomes, Paper presented at the Annual Meeting of the American Political Science Association, San Francisco, 31 August 2001.

KEATING, Michael; HUGHES, James - The Regional Challenge in Central and Eastern Europe. Territorial Restructuring and European Integration. Brussels: Peter Lang, 2003.

KRUGLASOV, Anatoliy - „Central and Eastern Europe Regional Reforms: From Dismantling a Soviet Model to Europeanizing a National One.' In PALERMO, Francesco; Parolari, Sara, Regional Dynamics in Central and Eastern Europe New Approaches to Decentralization. Leiden: Brill Online, 2013 pp. 8-34.

KAWECKA-WYRZYKOWSKA, Elżbieta, - "Financial Condition of Poland's Accession to the European Union.” In KAWECKA-WYRZYKOWSKA, Elżbieta; SYNOWIEC, Ewa. Poland and the European Union. Warsaw: Foreign Trade Research Institute, 2004.

LOUGHLIN, John; HENDRIKS, Frank; LIDSTROM, Anders - The Oxford Handbook of Local and Regional Democracy in Europe. New York: Oxford University Press, 2011.

MARCOU, Gerard - Between Economic Integration and Institutional Change: Models and Questions. In Local Government Brief, March 2001. 
MARCOU, Gérard - «L'adaptation des structures territoriales face à la politique régionale communautaire ». Revue d'études comparatives Est-Ouest, 2002, vol. 32, nº 3, p. 131-167.

MARCOU, Gerard - "Regionalisation for Development and Accession to the European Union: a Comparative Perspective.” In G. Marcou Regionalization for Development and Accession to the European Union: A Comparative Perspective, LGI Fellowship Series, 2002, pp. 11-25.

MAREK Dan; BAUN J. Michael - "The EU as a Regional Actor: The Case of the Czech Republic", Journal of Common Market Studies Vol. 40, No. 5, 2002, pp. 895-919.

PALERMO Francesco; PAROLARI, Sara - Regional Dynamics in Central and Eastern Europe New Approaches to Decentralization. S.1: Brill Online, 2013.

PERRY James L.; KRAEMER Kenneth L. - Public Management: Public and Private Perspectives. California: Mayfield, 1983.

POGATSA, Zoltan - "The Recentralisation of the Economic Development in Hungary." In PALERMO Francesco; PAROLARI, Sara - Regional Dynamics in Central and Eastern Europe New Approaches to Decentralization, S.1: Brill Online, 2013, pp. 147-174.

POLLITT Christopher; BOUCKAERT, Geert - Public Management Reform: A Comparative Analysis. 2nd expanded edn. Oxford: Oxford University Press, 2004, apud Geert Bouckaert, "Public Sector Reform in Central and Eastern Europe", Halduskultuur, 2009, vol 10, pp. 94104.

RĂDUCANU, Adina - "Europe of or With Regions: Regionalism in Romania", Journal of Public Administration, Finance and Law, Issue 3/2013, [September 23, 2013], http://www.jopafl.com/uploads/issue3/EUROPE_OF_OR_WITH_REGIONS_REGIONALIS M_IN_ROMANIA.pdf

ROKITA, Jan - Continuity and Change in Polish Policy after Regional Reform in 1998, Paper presented at the Conference "Regionalisation of Polish Politics" SSEES, 15-16 April 2002. 
SCHIMMELFENNIG, Frank Sedelmeier - Ulrich The Europeanization of Central and Eastern Europe, S.1. Cornell University Press, 2005.

SHERPEREEL, J.A. - "Sub-National Authorities in the EU's Post-Socialist States: Joining the Multi-Level Polity?” In European Integration, Vol. 29, No. 1, 2007, pp. 32-56.

STANUS, Cistina,; POP, Daniel - 'Romania.' In: Hubert Heinet, Hubert; Xavier Bertrana (eds.). The Second Tier of Local Government in Europe. Provinces, counties, départements and Landkreisein comparison. Abingdon \& NewYork: Routledge, 2011, pp. 205-223.

SUCIU, Marius - „Decentralization and regional development in Romania. An unfinished reform in search of a "European" model." In PALERMO, Francesco; PAROLARI, Sara Regional Dynamics in Central and Eastern Europe New Approaches to Decentralization. S.l. Brill Online, 2013 pp. 103-146.

SZCZERSKI, Krzysztof - "Securing Growth and Cohesion in Europeanized Conditions. The Role of Regional Development Bodies in Poland." In PALERMO, Francesco; PAROLARI, Sara - Regional Dynamics in Central and Eastern Europe New Approaches to Decentralization. Leiden: Brill Online, 2013 pp. 175-199.

TATUR, Melanie - "Conceptualising the Analysis of 'Making Regions' in Post Socialist Europe." In TATUR, Melanie - The Making of Regions in Post-socialist Europe: The Impact of Culture, Economic Structure and Institutions Case Studies from Poland, Hungary, Romania and Ukraine, Vol. 1, Wiesbaden, Vs Verlag, 2004, pp.11-23.

UNITA, Ramona - "Joining the EU's Multi-Level System of Governance - is there an East European Model of Regionalisation?" In HORGA, Ioan; IVAN, Adrian; BĂRBULESCU, Iordan Gheorghe - Regional and Cohesion Policy. Insights into of the Partnership Principle in the New Policy Design. Debrecen: University Press \& Oradea University Press, 2011, pp. 65-80. 
YODER J. - "Decentralisation and Regionalisation after Communism: Administrative and Territorial Reform in Poland and the Czech Republic", in Europe-Asia Studies, Vol. 55, No.2, 2003, pp. 263-286. 